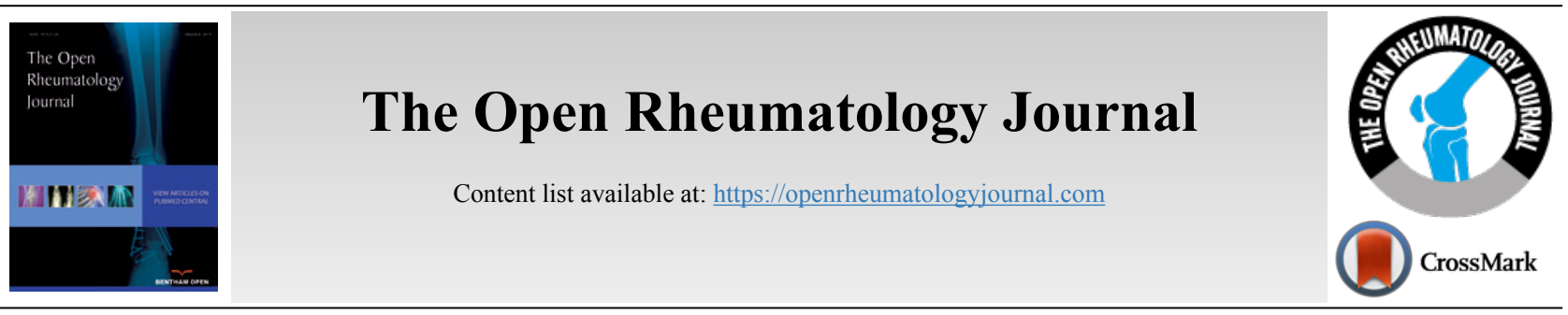

RESEARCH ARTICLE

\title{
Role of Protein Tyrosine Phosphatase (PTPN22) Gene [C1858T] Functional Variant in Genetic Susceptibility of Psoriatic Arthritis in Kuwaiti Arabs
}

\author{
Adel M. Al-Awadhi ${ }^{1,2}$, Mohammad Z. Haider ${ }^{3, *}$, Jalaja Sukumaran ${ }^{3}$, Asiya T. Mohammed ${ }^{3}$, Eman AH $\operatorname{Hasan}^{2}$ and \\ Youssef A. Bartella ${ }^{2}$
}

${ }^{1}$ Department of Medicine, Faculty of Medicine, Kuwait University, Kuwait

${ }^{2}$ Rheumatic Disease Unit, Amiri Hospital, Kuwait

${ }^{3}$ Department of Pediatrics/Obstetrics and Gynecology, Faculty of Medicine, Kuwait University, Kuwait

\begin{abstract}
:
Background:

Psoriatic arthritis (PsA) is a chronic, systemic inflammatory arthritic disease characterized by joint inflammation that is associated with cutaneous psoriasis, and can lead to pain, swelling, or stiffness in one or more joints. It results from a complex interplay between genetic, immunologic and environmental factors. A functional variant [C1858T] in the protein tyrosine phosphatase (PTPN22) gene, which encoded Arg620Trp in the lymphoid protein tyrosine phosphatase (LYP) has been shown to be a negative regulator of T-cell activation.

Objective:

The objective of this study was to investigate an association between PTPN22 gene [C1858T] functional variant and PsA in Kuwaiti patients.

Methods:

We have investigated the association of PTPN22 gene functional variant in 102 Kuwaiti patients with psoriatic arthritis and compared it to that in 214 healthy controls. The genotypes for the PTPN22 gene [C1858T] variant were determined by using a PCR-RFLP method and confirmed by DNA sequence analysis.
\end{abstract}

Results:

The frequency of homozygous variant genotype (TT) was found to be significantly higher in PsA patients compared to that in the controls (p $<0.0001)$. Collectively, the variant genotype was detected in homozygous and heterozygous combinations in $30 \%$ patients ( $p<0.0001$ ) compared to $16 \%$ in the controls. The frequency of variant genotype was found to be highest in the early-onset PsA patients (age $>25-34 \mathrm{y})$. No correlation was detected between the variant genotype (TT) and gender in the Kuwaiti PsA patients.

Conclusion:

Our data show a significant association of PTPN22 gene functional variant [C1958T] with PsA in Kuwaiti patients and highlight its role in determining the genetic susceptibility along with other factors.

Keywords: Genotype, PTPN22 gene, Functional variant, Psoriatic arthritis, Kuwait, Arthritic disease.

\section{Article History}

Received: April 23, 2020

Revised: June 25, 2020

Accepted: June 30, 2020

\section{INTRODUCTION}

The autoimmune diseases are characterized by abnormal immune responses against self-tissues and organs that are subjected to continuous inflammation, thus resulting in their dam-

\footnotetext{
* Address correspondence to this author at the Department of Pediatrics/Obstetrics and Gynecology, Faculty of Medicine, Kuwait University, Kuwait P.O. Box 24923, Safat 13110 Kuwait, Tel: +965-25319486;

Fax: +965-25338940; E-mail: m.haider@ku.edu.kw
}

age. Along with the abnormal immune system, genetic predisposition and environmental factors have also been implicated in autoimmune disease pathogenesis [1]. Psoriatic arthritis (PsA) is heterogeneous inflammatory arthritis, which occurs in patients with psoriasis and can cause pain, swelling, or stiffness in joints and may also result in movement disorders $[2,3]$. The disease severity has been shown to vary between patients and also within a specific patient over a period of time. 
The disease manifestation can vary from mild monooligoarthritis to severe erosive polyarthritis comparable with Rheumatic Arthritis (RA) [4]. In contrast to RA, manifestations such as dactylitis and enthesitis are common in patients with PsA, as is the case in patients suffering from other diseases within the seronegative spondylarthropathy group [5, 6]. In addition, in contrast to RA, the majority of the individuals with PsA are seronegative for Rheumatoid Factor (RF) and anticitrullinated protein-peptide antibodies (ACPA) [7, 8]. A number of genes have been associated with PsA in previous reports mainly from Caucasians and some of these genes are common to a number of other autoimmune diseases [9 - 11]. Epidemiological evidence has demonstrated a high heritability of psoriatic arthritis compared with psoriasis vulgaris [9, 12]. It has been reported that genetic susceptibility can be considered as a contributing factor in approximately 50\% PsA patients who have a family history of spondyloarthropathies or cutaneous psoriasis [3]. More recently, the genome-wide association studies (GWAS) have demonstrated that the genetic contributions of psoriatic disease account for less than $25 \%$ of heritability $[1,10]$.

The protein tyrosine phosphatase non-receptor 22 (PTPN22) gene, located on chromosome 1p13, codes for a protein, LYP, which is considered as a negative regulator of $\mathrm{T}$ cells [13]. A Single Nucleotide Polymorphism (SNP) rs2476601 [C1858T], located in exon 14 of the PTPN22 gene, results in a functional variant, Arg620Trp, which has been associated with several autoimmune diseases [13 - 16]. Previous studies investigating an association between PTPN22 gene [C1858T] functional variant and susceptibility to PsA have shown conflicting results [12, 14 - 16]. These inconsistent results have been attributed to various causes such as small sample sizes, racial or ethnic differences and clinical or genetic heterogeneity [14 - 16]. Therefore, it is important to study the ethnicity-specific association of PTPN22 gene [C1858T] functional variant with PsA to determine its role in genetic predisposition in different populations.

The aim of this study was to investigate the possible association of PTPN22 gene [C1858T] functional variant in a completely different population/ethnic group (Kuwaiti Arab patients with PsA) and controls in order to determine its impact on genetic susceptibility of PsA.

\section{MATERIALS AND METHODS}

This study included 102 Kuwaiti Arab patients with psoriatic arthritis (PsA) and 214 healthy controls of matching ethnicity. The PsA patients were seen regularly at the Rheumatic Disease Unit, Amiri Hospital, Kuwait. The diagnosis of PsA was based on the presence of inflammatory arthritis associated with psoriasis, usually with no rheumatoid factor in the serum [5]. The diagnosis of PsA had been made at least six months prior to enrollment in the study. Detailed clinical information was obtained from all patients, including age, gender, age at disease onset, family history of psoriasis and/or PsA, and clinical manifestations. Patients were considered to have 'early-onset' PsA if disease onset was at any age younger than 40 years, and 'late-onset' PsA if age at onset was after their $40^{\text {th }}$ birthday. The controls were healthy
Kuwaiti nationals and were evaluated by a trained Rheumatologist for their health status. They did not have a history of autoimmune or rheumatic disorders or other diseases of known genetic or hereditary predisposition. The subjects included in the study, both patients and controls were unrelated to each other but were matched for age and gender.

Blood (approximately $5 \mathrm{ml}$ ) was withdrawn from all the study subjects and anticoagulated by EDTA. A previously described method was used to isolate total genomic DNA [17]. The genotypes of a functional variant $+1858 \mathrm{C} \rightarrow \mathrm{T}$ ( $\mathrm{rs} 2476601)$ in the PTPN22 gene were identified by polymerase chain reaction-restriction enzyme fragment length polymorphism (PCR-RFLP) method $[18,19]$. In order to amplify a $218 \mathrm{bp}$ DNA fragment, the primers: Forward primer: 5'ACTGATAATGTTGCTTCAACGG-3' and reverse primer:5'TCACCAGCTTCCTCAACCAC-3' were used. The PCR mixture contained 10x PCR buffer (Applied BioSystems, USA); $0.2 \mathrm{mM}$ of dNTPs (deoxyribonucleotide triphosphates); $1.5 \mathrm{mM} \mathrm{MgCl}_{2} ; 20$ pmol of each primer, $200 \mathrm{ng}$ template DNA and 1 U AmpliTaq DNA polymerase (Applied BioSystems). The PCR program consisted of denaturation at $94 \mathrm{C}$ for $2 \mathrm{~min}$ followed by 35 cycles of $94 \mathrm{C}$ for 30 seconds, $60 \mathrm{C}$ for 30 seconds and $72 \mathrm{C}$ for 30 seconds and an extension step at $72 \mathrm{C}$ for 7 minutes. The amplification products were digested with restriction enzyme $R s a \mathrm{I}$ at $37 \mathrm{C}$ for $90 \mathrm{~min}$. The cleavage products were analyzed by $2 \%$ agarose gel electrophoresis and visualized under UV light after staining with ethidium bromide. The absence of RsaI restriction enzyme site in the 218 bp PCR product was associated with the $1858 \mathrm{~T}$ allele, while in the presence of $1858 \mathrm{C}$ allele, $176 \mathrm{bp}$ and $42 \mathrm{bp}$ cleavage products were detected. PCR products from a heterozygous individual produced the 218, 176 and $42 \mathrm{bp}$ cleavage products. Sanger's DNA sequencing method was used to sequence the PCR amplicons on ABI 3130 genetic analyzer to confirm the genotypes.

The data collected were analyzed using the Statistical Package for Social Sciences (SPSS) ver.25, Chicago, IL, USA. The frequency of genotypes and alleles from PsA patients and controls were determined by direct counting. The Confidence Interval (CI) was fixed at $95 \%$ and statistical significance was set at $\mathrm{P}<0.05$ (two-tailed). Fisher's Exact test was used to determine the statistical significance of the differences between genotype and allele frequency in PsA patients and controls. For calculation of the statistical significance in co-dominant and dominant models, the genotype frequency in homozygous CC subjects and the ' $\mathrm{C}$ ' allele frequency were considered as reference (assumed to be associated with the least risk of PsA). In the case of the dominant model, the genotype frequencies of $\mathrm{CT}$ and TT were combined (PsA patients having at least one variant ' $\mathrm{T}$ ' allele of the PTPN22 gene). One possible limitation of this study might be that in some comparisons, e.g., with age and gender, the presence of low numbers in the study groups could potentially result in type-II errors. The genotype distribution was tested for Hardy Weinberg equilibrium by the goodness of fit method using MSTAT software.

\section{RESULTS}

The genotypes of the PTPN22 gene functional variant 
[C1858T] were determined by using the PCR-RFLP method as described in the Methods section. A representative gel showing the method used for the detection of various genotypes of the $P T P N 22$ gene $[\mathrm{C} 1858 \mathrm{~T}]$ functional variant is presented in Fig. (1). The baseline characteristics of Kuwaiti PsA patients included in this study have been presented in Table $\mathbf{1}$.

The homozygous variant (TT) genotype frequency of the PTPN22 gene C1858T variant was found to be significantly higher in Kuwaiti PsA patients than that in the controls (OR 9.06, Table 2). Collectively, the homozygous (TT) and heterozygous (CT) genotypes of the PTPN22 gene C1858T polymorphism (i.e., individuals with at least one variant $\mathrm{T}$ allele) were detected in $30 \%$ PsA patients compared to $16 \%$ in the controls (Table 2). The genotype frequency was not significantly different in the case of heterozygous CT genotype
(Table 2). The power calculation for the variant TT genotype (OR 9.06) provided the study power of $100 \%$ for the estimation of the PsA risk. The differences were also significant between patients and controls when the allele frequencies of ' $\mathrm{C}$ ' and ' $\mathrm{T}$ ' alleles were compared $(\mathrm{P}<0.0001$; Table 2).

The distribution of PTPN22 gene polymorphism genotypes was compared in Kuwaiti PsA patients stratified on the basis of age-distribution pattern and the data is presented in Fig. (2). The frequency of variant genotypes TT was $0 \%$ in $0-4 \mathrm{y}$ age group, $12.5 \%$ in $15-24 \mathrm{y}, 16.7 \%$ in $25-34 \mathrm{y}, 10 \%$ in $35-44 \mathrm{y}$ and $20 \%$ in PsA patients with $>45 \mathrm{y}$ of age (Fig. 2). When the two genotypes, i.e., TT and CT (with at least one variant allele) were considered together, the frequency was $12.5 \%$ in $15-24 \mathrm{y}$, $42 \%$ in $25-34 y, 33 \%$ in $35-44 y$ and $30 \%$ in respective agegroups of Kuwaiti PsA patients (Fig. 2).

Table 1. Baseline characteristics of Kuwaiti psoriatic arthritis $($ PsA) patients included in the study $(\mathbf{n}=102)$

\begin{tabular}{|c|c|}
\hline Mean age at diagnosis $( \pm \mathrm{SD})$ years & $39.2( \pm 9.0)$ \\
\hline Median disease duration (range) months & $60(6-240)$ \\
\hline Clinical manifestations: & $\mathrm{n}(\%)$ \\
\hline Asymmetric polyarthritis & $78(76.4)$ \\
\hline Symmetric polyarthritis & $14(13.7)$ \\
\hline Oligo-arthritis & $10(9.8)$ \\
\hline Spondylitis & $20(19.6)$ \\
\hline Dactylitis & $48(47.1)$ \\
\hline Enthesitis & $20(19.6)$ \\
\hline
\end{tabular}

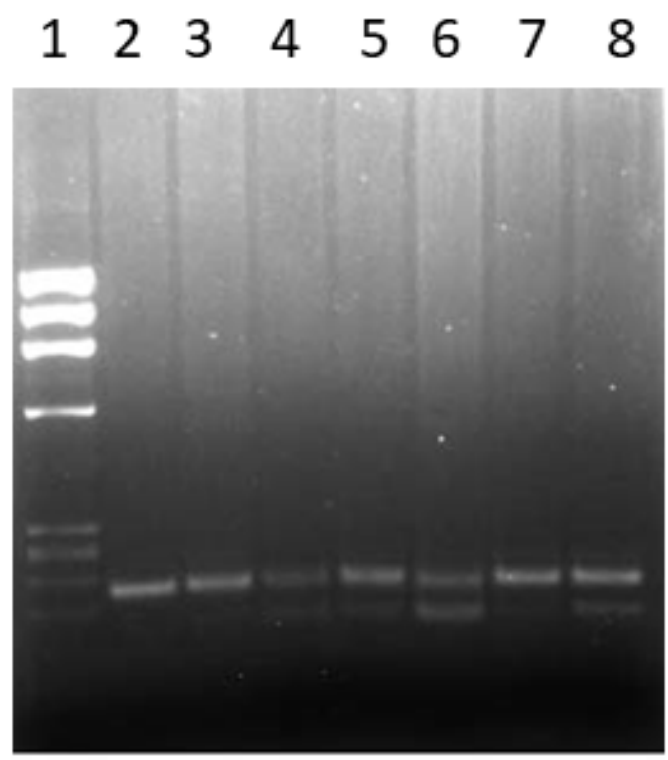

Fig. (1). Detection of PTPN22 gene functional variant [C1858T; rs2476601] genotypes. PCR amplification of genomic DNA was carried out (details given in Methods) and the products of amplification were cleaved with restriction enzyme RsaI. Lane 1, phiX174 HaeIII cut $M_{r}$ markers; lane 2,3,7, products from subjects having TT genotype; lanes 4,5,6,8, products from subjects having CT genotype. RsaI cleavage products were analyzed on $2 \%$ agarose gel and visualized under UV light after staining with ethidium. bromide. 


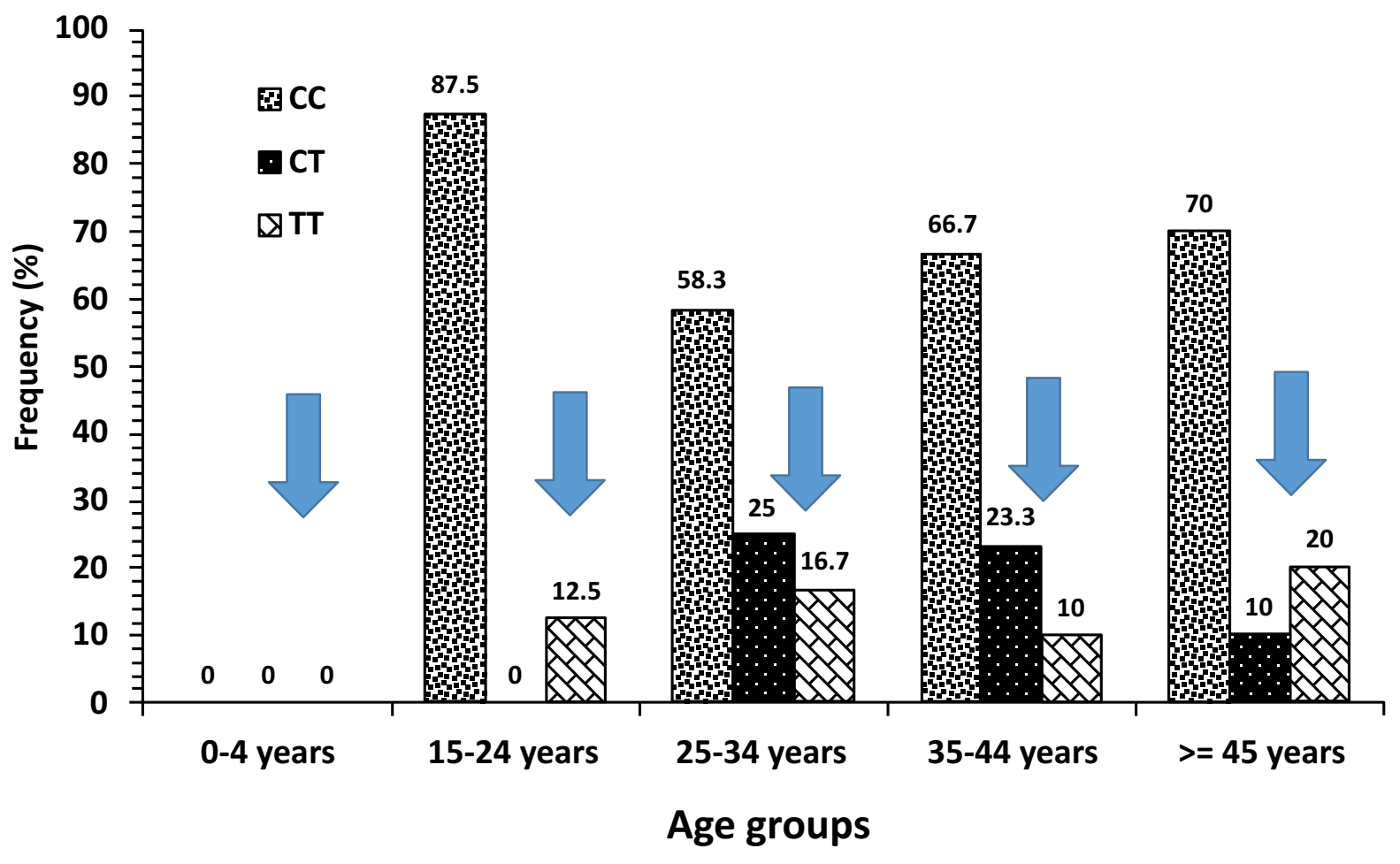

Fig. (2). Correlation between PTPN22 gene C1858T variant genotypes in subgroups of Kuwaiti PsA patients. The Kuwaiti PsA patients group was sub-divided on the basis of age-of-onset of the disease. The arrows indicate distribution of the susceptibility genotypes CT and TT in different age-groups having frequency of $0 \%, 12.5 \%, 42 \%, 33 \%$ and $30 \%$ respectively. CC, CT and TT are the genotypes of PTPN22 gene [C1858T] functional variant.

Table 2. Genotype and allele frequencies of PTPN22 gene [C1858T] functional variant in Kuwaiti PsA patients and controls.

\begin{tabular}{|c|c|c|c|c|}
\hline Genotypes & $\begin{array}{c}\text { Patients } \\
\mathrm{N}=102(\%)\end{array}$ & $\begin{array}{c}\text { Controls } \\
\mathrm{N}=214(\%)\end{array}$ & OR $(95 \% \mathrm{CI})^{*}$ & P-value** \\
\hline \multicolumn{5}{|l|}{ Co-dominant } \\
\hline $\mathrm{CC}$ & $71(70)$ & $180(84)$ & 1.0 (Reference) ${ }^{* * *}$ & \\
\hline $\mathbf{C T}$ & $15(14)$ & $32(15)$ & $1.19(0.61-2.33)$ & 0.6 \\
\hline TT & $16(16)$ & $2(1)$ & $9.06(2.55-14.50)$ & $<0.0001$ \\
\hline \multicolumn{5}{|l|}{ Dominant } \\
\hline $\mathrm{CC}$ & $71(70)$ & $180(84)$ & 1.0 (Reference) & \\
\hline CT/TT & $31(30)$ & $34(16)$ & $2.31(1.32-4.04)$ & 0.005 \\
\hline Alleles & $\mathrm{N}=204(\%)$ & $\mathrm{N}=428(\%)$ & & \\
\hline C-allele & $157(77)$ & $392(92)$ & 1.0 (Reference) & \\
\hline T-allele & $47(23)$ & $36(8)$ & $3.26(2.03-5.23)$ & $<0.0001$ \\
\hline
\end{tabular}

$* \mathrm{OR}(95 \% \mathrm{CI})$, odds ratio at $95 \%$ confidence interval; **P-values were considered significant when below $<0.05 . * * *$ Genotype frequency in the case of homozygous CC subjects and allele frequency of ' $\mathrm{C}$ ' were considered as reference (assuming to be associated with least risk of PsA) for calculation of statistical significance using Fisher's Exact test.

Table 3. Correlation of $P T P N$ gene [C1858T] functional variant genotypes with gender in Kuwaiti PsA patients and controls

\begin{tabular}{|c|c|c|c|c|}
\hline PTPN22 genotype/ gender & Patients n (\%) & Control n (\%) & OR (95\% CI)* & P-value** \\
\hline & $\mathbf{n}=\mathbf{7 1}$ & $\mathbf{n}=\mathbf{1 7 7}$ & & \\
\hline Male CC & $33(46.5)$ & $62(35)$ & $1.61(0.92-2.82$ & 0.13 \\
\hline Female CC & $38(53.5)$ & $115(65)$ & $0.62(0.35-1.09)$ & 0.13 \\
\hline Male CT & $\mathbf{n}=\mathbf{1 5}$ & $\mathbf{n}=\mathbf{3 2}$ & & 0.20 \\
\hline Female CT & $3(20)$ & $13(40.6)$ & $0.37(0.09-1.57)$ & 0.20 \\
\hline & $12(80)$ & $19(59.4)$ & $2.73(0.64-8.66)$ & \\
\hline
\end{tabular}


(Table 3) cont.....

(Table 3) cont....
\begin{tabular}{|c|c|c|c|}
\hline PTPN22 genotype/ gender & Patients n (\%) & Control n (\%) & OR (95\% CI)* \\
\hline Male TT & $\mathbf{n = 7 1}$ & $\mathbf{n = 1 7 7}$ & \\
\hline Female TT & $5(31.25)$ & $1(50)$ & $0.45(0.02-8.84)$ \\
\hline *OR (95\% CI), odds ratio at 95\% confidence interval; **P-values were considered significant when below $<0.05 . \mathrm{fd}$ & $2.20(0.11-9.76)$ \\
\hline
\end{tabular}

The genotype frequencies of PTPN22 gene functional variant $[\mathrm{C} 1858 \mathrm{~T}]$ were compared between patients and controls in relation to the gender and the data is presented in Table 3. No correlation was found between gender and the manifestation of PsA in Kuwaiti patients (Table 3). In the case, of PsA patients with TT genotype, majority 11/16 (69\%) were females, while in comparison, TT genotype was detected in $31 \%$ of the male PsA patients (Table 3). A similar distribution pattern was noted in the case of heterozygous CT genotype, in which case, $80 \%$ of the females had the CT genotype (Table 3 ).

\section{DISCUSSION}

The most striking finding in this study is the significant association detected between the homozygous functional variant (TT) genotype of the PTPN22 gene and clinical presentation of psoriatic arthritis in Kuwaiti Arabs. The PTPN22 gene encodes a functional protein tyrosine phosphatase, LYP, which acts as a regulator of the negative regulatory kinase in $\mathrm{T}$ cells. It has been shown to play a role in suppressing $\mathrm{T}$ cell activation and, therefore, maybe the mechanism by which association is likely to contribute to the genetic susceptibility of PsA and indeed for several other autoimmune disorders [13].

Previous association studies on the PTPN22 gene [C1858T], functional variant and PsA have yielded conflicting results. Hinks et al. [14] did not find an association of this variant with PsA in a patient population from the UK. Similarly, no association was detected between PTPN22 gene [C1858T] functional variant and PsA in German patients when the whole of the patient group was considered; however, in the males, a significantly higher proportion carried the risk allele ' $\mathrm{T}$ ' [15]. A recent study from Greece did not find an association between PTPN22 gene [C1858T] variant and PsA [20]. However, this report from Greece did find an association between TYK2 (tyrosine kinase-2) and STAT4 (signal transducer and activation of transcription-4) genes and PsA and also reported an overlap between PsA and rheumatoid arthritis (RA). In contrast to these negative associations, our results from Kuwaiti Arabs show a significant positive association between PsA and PTPN22 gene [1858T] functional variant (Table 2). However, unlike the study from Greece, we did not find any significant overlap between PsA and RA in the Kuwaiti Arab patients with PsA. In a meta-analysis, which evaluated the risk of psoriasis in relation to PTPN22 gene [C1858T] functional variant, a positive association between psoriasis and the PTPN22 gene 1858T allele was reported and this association was found to be stronger among the subjects with PsA [21]. Butt et al. [16] investigated the association between PTPN22 gene [1858T] functional variant and psoriatic arthritis in two populations. They reported a moderate association of the PTPN22 gene [C1858T] variant with PsA in a patient population from Toronto, but not in another population from Newfoundland, in which no difference in the risk allele (T) frequency was detected [16]. On the basis of these divergent results, the authors argued that the association might be disease and population-specific [16]. A positive association between PTPN22 gene functional variant [C1858T] and PsA has been reported in patients from Sweden [21]. This report also showed that carriers of the variant ' $T$ ' allele had a significantly higher number of deformed joints [21]. In a study from Saudi Arabia, a weak association between the heterozygous CT genotype of the PTPN22 gene functional variant was detected in psoriasis patients [22]. Interestingly, the homozygous TT genotype was not detected at all in either patients or the controls in this study from Saudi Arabia [22]. Although psoriasis and psoriatic arthritis are interrelated disorders, PsA is a distinct entity with its own epidemiological, clinical and genetic features [1]. Furthermore, PsA exhibits much greater heritability among the first degree relatives than psoriasis [10]. To our knowledge, the majority of genetic association studies on PTPN22 gene with PsA have been carried out in Caucasians and the only study from the Middle East is the one mentioned above from Saudi Arabia on psoriasis [22]. The prevalence of PTPN22 [C1858T] functional variant has been shown to vary in different ethnic groups, e.g., it was found to be low in Asians and Africans and was virtually absent in Han Chinese [23, 24]. It has been reported that in Europe, a distinct North-South gradient exists in the prevalence of the PTPN22 gene [C1858T] functional variant [25].

In our study, the highest frequency of PTPN22 gene functional variant [1858T] was noted in the age range $25-34 \mathrm{y}$ amongst the Kuwaiti PsA patients $(42 \%$ of the PsA patients had at least one variant ' $\mathrm{T}$ ' allele, i.e., combined TT and CT genotypes) compared to $33 \%$ in $35-44$ y age-group and $30 \%$ in $>45 y$ age-group, respectively (Fig. 2). This demonstrated that a higher relative proportion of early-onset PsA patients $(<40 \mathrm{y}$ of age) carried at least one ' $\mathrm{T}$ ' risk-allele of the PTPN22 gene functional variant $[\mathrm{C} 1858 \mathrm{~T}]$, further highlighting its role and contribution in genetic susceptibility of PsA in Kuwaiti Arabs.

We did not find any correlation between the frequency of PTPN22 gene functional variant and the gender in Kuwaiti Arabs with PsA (Table 3). The gender-distribution in our patients showed the presence of a higher number of females in our study group. In the study from Saudi Arabia on psoriasis, it was reported that allele $\mathrm{T}$ and $\mathrm{CT}$ genotype were more prevalent in female psoriasis patients than in the males, although the differences were not found to be statistically significant [22]. In another study from Germany, the male predominant correlation of variant ' $\mathrm{T}$ ' allele has been reported in PsA patients [15]. However, our results in Kuwaiti PsA patients did not find a gender-correlation.

Kuwaiti Arabs constitute nearly $45 \%$ of the population of the State of Kuwait and the population itself is quite diverse. It is a small country located in the north of the Arabian Gulf. There is a high incidence of consanguinity $(54 \%)$, which has 
resulted in the familial clustering of chronic disorders [26]. The original settlers of Kuwait had migrated from Najd, an area, which is now part of eastern and central Saudi Arabia. It has been reported that the ethnic origin of Kuwaiti Arabs is diverse; nearly half are of Arab origin, some are Bedouins and the rest are migrants [27]. The Arab citizens of the Gulf States, in general, are thought to have resulted from admixtures between various ethnic groups such as Persians, Turks, South Asians, Europeans and Africans [27]. The genotype frequency of PTPN22 gene function variant [C1858T] reported in this study in Kuwaiti PsA patients is amongst the highest (TT, 16\% and combined TT and CT in 30\% PsA patients) compared to any other population/ethnic group. This, in our opinion, can possibly be due to a combined effect of unique ethnic/genetic background along with a very high rate of consanguinity in Kuwaiti Arabs and can, therefore, at least partially explain the high incidence of autoimmune diseases, including PsA in Kuwait.

\section{CONCLUSION}

Our data demonstrate a significant association of PTPN22 gene $[\mathrm{C} 1858 \mathrm{~T}]$ functional variant with psoriatic arthritis in Kuwaiti Arabs and highlight its involvement in genetic susceptibility along with other factors. The highest frequency of the homozygous TT genotype of the PTPN22 gene [C1858T] functional variant was detected in the early-onset age-group (25-34y) in Kuwaiti PsA patients, further highlighting its role in genetic susceptibility to PsA.

\section{LIST OF ABBREVIATIONS}

$$
\begin{array}{ll}
\text { PTPN22 } & =\text { Protein Tyrosine Phosphatase Receptor Type N22 } \\
\text { PSA } & =\text { Psoriatic Arthritis } \\
\text { LYP } & =\text { Lymphoid Protein Tyrosine Phosphatase } \\
\text { PCR } & =\text { Polymerase Chain Reaction } \\
\text { RFLP } & =\text { Restriction Fragment Length Polymorphism } \\
\text { RA } & =\text { Rheumatoid Arthritis } \\
\text { RF } & =\text { Rheumatoid Factor } \\
\text { ACPA } & =\text { Anti-citrullinated Protein-Peptide Antibody } \\
\text { GWAS } & =\text { Genome-wide Association Study } \\
\text { SNP } & =\text { Single Nucleotide Polymorphism } \\
\text { UV } & =\text { Ultra-Violet } \\
\text { BP } & =\text { Base Pair } \\
\text { CI } & =\text { Confidence Interval } \\
\text { OR } & =\text { Odds Ratio } \\
\text { STAT4 } & \text { Signal Transduction and Activation of Transcription-4. }
\end{array}
$$

\section{ETHICS APPROVAL AND CONSENT TO PARTI- CIPATE}

The Ethics Committee of Health Sciences Centre, Kuwait University approved this study (Ref. No. VDR/EC/3243).

\section{HUMAN AND ANIMAL RIGHTS}

No Animals were used in this research. All human research procedures followed were in accordance with the ethical standards of the committee responsible for human experimentation (institutional and national), and with the Helsinki Declaration of 1975, as revised in 2013.

\section{CONSENT FOR PUBLICATION}

Written informed consent was obtained from all the patients when they were enrolled.

\section{AVAILABILITY OF DATA AND MATERIALS}

The authors confirm that the data supporting the findings of this study are available within the article.

\section{FUNDING}

This study was funded by the Kuwait University, General Research Support Facility under grant no. GF/Med/03-20.

\section{CONFLICT OF INTERESTS}

The authors declare no conflict of interest, financial or otherwise.

\section{ACKNOWLEDGEMENTS}

We would like to thank the patients for participation in the study and the hospital staff for their assistance.

\section{REFERENCES}

[1] Furst DE, Belasco J, Louie JS. Genetic and inflammatory factors associated with psoriatic arthritis: Relevance to diagnosis and management. Clin Immunol 2019; 202: 59-75.

[http://dx.doi.org/10.1016/j.clim.2019.02.001] [PMID: 30738143]

[2] Reich K, Krüger K, Mössner R, Augustin M. Epidemiology and clinical pattern of psoriatic arthritis in Germany: A prospective interdisciplinary epidemiological study of 1511 patients with plaquetype psoriasis. Br J Dermatol 2009; 160(5): 1040-7.

[http://dx.doi.org/10.1111/j.1365-2133.2008.09023.x]

[PMID: 19210498]

[3] FitzGerald O, Haroon M, Giles JT, Winchester R. Concepts of pathogenesis in psoriatic arthritis: Genotype determines clinical phenotype. Arthritis Res Ther 2015; 17: 115.

[http://dx.doi.org/10.1186/s13075-015-0640-3] [PMID: 25948071]

[4] Wang L, Wang FS, Gershwin ME. Human autoimmune diseases: A comprehensive update. J Intern Med 2015; 278(4): 369-95. [http://dx.doi.org/10.1111/joim.12395] [PMID: 26212387]

[5] Helliwell PS. Established psoriatic arthritis: Clinical aspects. J Rheumatol Suppl 2009; 83(Suppl. 83): 21-3. [http://dx.doi.org/10.3899/jrheum.090215] [PMID: 19661532]

[6] Dougados M, van der Linden S, Juhlin R, et al. The European Spondylarthropathy Study Group preliminary criteria for the classification of spondylarthropathy. Arthritis Rheum 1991; 34(10): 1218-27.

[http://dx.doi.org/10.1002/art.1780341003] [PMID: 1930310]

[7] Alenius GM, Berglin E, Rantapää Dahlqvist S. Antibodies against cyclic citrullinated peptide (CCP) in psoriatic patients with or without joint inflammation. Ann Rheum Dis 2006; 65(3): 398-400. [http://dx.doi.org/10.1136/ard.2005.040998] [PMID: 16096328]

[8] Taylor W, Gladman D, Helliwell P, Marchesoni A, Mease P, Mielants H. CASPAR Study Group. Classification criteria for psoriatic arthritis: Development of new criteria from a large international study. Arthritis Rheum 2006; 54(8): 2665-73.

[http://dx.doi.org/10.1002/art.21972] [PMID: 16871531]

[9] Duffin KC, Chandran V, Gladman DD, Krueger GG, Elder JT, Rahman P. Genetics of psoriasis and psoriatic arthritis: Update and future direction. J Rheumatol 2008; 35(7): 1449-53. [PMID: 18609743]

[10] O'Rielly DD, Rahman P. Genetic, epigenetic and pharmacogenetic aspects of psoriasis and psoriatic arthritis. Rheum Dis Clin North Am 2015; 41(4): 623-42.

[http://dx.doi.org/10.1016/j.rdc.2015.07.002] [PMID: 26476223]

[11] Al-Awadhi AM, Haider MZ, Sukumaran J, Balakrishnan S. High prevalence of protein tyrosine phosphatase non-receptor N22 gene 
functional variant R620W in systemic lupus erythematosus patients from Kuwait: Implications for disease susceptibility. BMC Rheumatol 2018; $2: 7$.

[http://dx.doi.org/10.1186/s41927-018-0015-x] [PMID: 30886958]

[12] Juneblad K, Johansson M, Rantapää-Dahlqvist S, Alenius G-M. Association between the PTPN22 $+1858 \mathrm{C} / \mathrm{T}$ polymorphism and psoriatic arthritis. Arthritis Res Ther 2011; 13(2): R45. [http://dx.doi.org/10.1186/ar3284] [PMID: 21410964]

[13] Vang T, Congia M, Macis MD, et al. Autoimmune-associated lymphoid tyrosine phosphatase is a gain-of-function variant. Nat Genet 2005; 37(12): 1317-9.

[http://dx.doi.org/10.1038/ng1673] [PMID: 16273109]

[14] Hinks A, Barton A, John S, et al. Association between the PTPN22 gene and rheumatoid arthritis and juvenile idiopathic arthritis in a UK population: further support that PTPN22 is an autoimmunity gene. Arthritis Rheum 2005; 52(6): 1694-9.

[http://dx.doi.org/10.1002/art.21049] [PMID: 15934099]

[15] Hüffmeier U, Reis A, Steffens M, et al. Male restricted genetic association of variant R620W in PTPN22 with psoriatic arthritis. J Invest Dermatol 2006; 126(4): 932-5.

[http://dx.doi.org/10.1038/sj.jid.5700179] [PMID: 16456530]

[16] Butt C, Peddle L, Greenwood C, Hamilton S, Gladman D, Rahman P. Association of functional variants of PTPN22 and tp53 in psoriatic arthritis: A case-control study. Arthritis Res Ther 2006; 8(1): R27. [http://dx.doi.org/10.1186/ar1880] [PMID: 16507123]

[17] Sambrook J, Freitsch EF, Maniatis T. Molecular cloning: A laboratory manual. 2nd ed. NY, USA: Cold Spring Harbor Laboratory 1989.

[18] Steck AK, Liu S-Y, McFann K, et al. Association of the PTPN22/LYP gene with type 1 diabetes. Pediatr Diabetes 2006; 7(5): 274-8. [http://dx.doi.org/10.1111/j.1399-5448.2006.00202.x] [PMID: 17054449]

[19] Haider MZ, Rasoul MA, Al-Mahdi M, Al-Kandari H, Dhaunsi GS. Association of protein tyrosine phosphatase non-receptor type 22 gene functional variant C1858T, HLA-DQ/DR genotypes and autoantibodies with susceptibility to type-1 diabetes mellitus in
Kuwaiti Arabs. PLoS One 2018; 13(6)e0198652 [http://dx.doi.org/10.1371/journal.pone.0198652] [PMID: 29924845]

[20] Myrthianou E, Zervou MI, Budu-Aggrey A, et al. Investigation of the genetic overlap between rheumatoid arthritis and psoriatic arthritis in a Greek population. Scand J Rheumatol 2017; 46(3): 180-6.

[http://dx.doi.org/10.1080/03009742.2016.1199734]

[PMID: 27440135]

[21] Chen YF, Chang JS. PTPN22 C1858T and the risk of psoriasis: A meta-analysis. Mol Biol Rep 2012; 39(8): 7861-70.

[http://dx.doi.org/10.1007/s11033-012-1630-z] [PMID: 22544573]

[22] Bin Huraib G, Al Harthi F, Arfin M, Rizvi S, Al-Asmari A. The protein tyrosine phosphatase nonreceptor 22 (PTPN22) R620W functional polymorphism in Psoriasis. Clin Med Insights Arthritis Musculoskelet Disord 2018; 111179544117751434

[http://dx.doi.org/10.1177/1179544117751434] [PMID: 29348710]

[23] Lee HS, Korman BD, Le JM, et al. Genetic risk factors for rheumatoid arthritis differ in Caucasian and Korean populations. Arthritis Rheum 2009; 60(2): 364-71

[http://dx.doi.org/10.1002/art.24245] [PMID: 19180477]

[24] Zhang ZH, Chen F, Zhang XL, Jin Y, Bai J, Fu SB. PTPN22 allele polymorphisms in 15 Chinese populations. Int J Immunogenet 2008; 35(6): 433-7.

[http://dx.doi.org/10.1111/j.1744-313X.2008.00803.x] [PMID: 19046301]

[25] Mori M, Yamada R, Kobayashi K, Kawaida R, Yamamoto K. Ethnic differences in allele frequency of autoimmune-disease-associated SNPs. J Hum Genet 2005; 50(5): 264-6. [http://dx.doi.org/10.1007/s10038-005-0246-8] [PMID: 15883854]

[26] Al-Awadi SA, Moussa MA, Naguib KK, et al. Consanguinity among the Kuwaiti population. Clin Genet 1985; 27(5): 483-6. [http://dx.doi.org/10.1111/j.1399-0004.1985.tb00236.x] [PMID: 4006273]

[27] Teebi AS, Farag TI. Population dimensions in Arab World.Genetic Disorders among Arab populations. Oxford: Oxford University Press 1997; pp. 29-51.

(C) 2020 Al-Awadhi etal.

This is an open access article distributed under the terms of the Creative Commons Attribution 4.0 International Public License (CC-BY 4.0), a copy of which is available at: (https://creativecommons.org/licenses/by/4.0/legalcode). This license permits unrestricted use, distribution, and reproduction in any medium, provided the original author and source are credited. 